GLOBAL JOURNAL OF PURE AND APPLIED SCIENCES VOL. 26, 2020: 9-14

COPYRIGHT@ BACHUDO SCIENCE CO. LTD PRINTED IN NIGERIA ISSN 1118-0579

www.globaljournalseries.com, Email: info@globaljournalseries.com

\title{
FORAMINIFERAL ANALYSIS AND PALEOENVIRONMENTS OF SEDIMENTS IN WELL -AA, DEEPWATER OFFSHORE, NIGER DELTA, NIGERIA.
}

UMOH EKAETE ENAMEKERE AND FASINA PEACE OLUWASEYI

(Received 16 January 2019; Revision Accepted 27 March 2020)

\begin{abstract}
Foraminiferal analysis was carried out on twenty five (25) ditch cutting samples from well -AA, offsore Niger Delta covering a depth interval of $9000 \mathrm{ft}-11025 \mathrm{f}$. The study was aimed at age deduction, zoning the well, and interpreting the paleoenvironment of deposition. Lithostratigraphic description carried out on the sample revealed that the bulk lithofacies constitute shale with streaks of sand (fine-medium) between $9170 \mathrm{ft}-9210 \mathrm{ft}$ and $9360 \mathrm{ft}-9380 \mathrm{ft}$. The entire analysed interval was barren of planktonic foraminifera while depth 9960ft revealed a spot occurrence of Lagena spp, representing the only calcareous benthic foraminifera recovered in the entire interval. Few to common occurrences of deepwater agglutinated foraminifera were found in the well, dominated by some species of Haplophragmoides spp and Haplophragmoides narivaensis. Other foraminifera with rare and scattered occurrence includes, Cribrostomides spp, Bathysiphon spp, Troahammina spp, Cyclammina spp, Cyclammina cancellata, Valvulina spp, and Glomospira spp. The only microfaunal associated accessory recovered is ostracod at depth $1080 \mathrm{ft}$. The analysed intervals was assigned a Middle - Late Miocene (N17 and older age) based on the FDO of Haplophragmoides narivaensis. The environment of deposition is based on the distribution of typical deep water arenaeceous foraminifera species recovered in the study. The predominance of the arenaeceous forms over calcareous forms suggest outer shelf environment of deposition.
\end{abstract}

KEYWORDS: Foraminifera, Palaeoenvironment, Niger delta, Biostratigraphy.

\section{INTRODUCTION}

The Niger Delta is an important sedimentary basin with oil and gas fields in Nigeria. The basin is situated in the Gulf of Guinea (Figure 1) as defined by Klett et al. (1997). From the Eocene to Recent, the development of the Delta has prograded southwestward, forming depobelts that represents the active parts of the delta, (Doust and Omatsola, 1990).

The Niger Delta basin contains one recognized petroleum system the Akata-Agbada Petroleum System with numerous exploratory wells (Ekweozor and Daukoru, 1994; Kulke,1995). The relatively large amount of data obtained from several researchers (Ozumba, 1995; Fadiya, 1999; Bassey and Alalade, 2005; Umoh et al, 2011; Omoboriowo et al, 2011, Oloto and Promise, 2014; Fadiya et al, 2014; Umoh, 2015; Boboye et al, 2017; Ifeoluwadun and Saka, 2018) in the Niger delta has led to a better understanding of the subsurface formations that characterise the basin and more quest to the discovery of oil and gas in the region. This study seeks to determine the bioevents, age of sediments and environment of deposition as contribution to the existing datasets of the Niger delta.

\section{LOCATION OF THE STUDY AREA.}

The study area lies within the Niger Delta between Longitudes $3^{\circ} \mathrm{E}$ and $9^{\circ} \mathrm{E}$ and Latitudes $4{ }^{\circ} \mathrm{N}$ and $5^{\circ} 2^{\prime} \mathrm{N}$. (Figure 1). The study well $-\mathrm{AA}$, is an offshore well belonging to the OML 118 block.

Umoh Ekaete Enamekere, Ajayi Crowther University, PMB 1066, Oyo. Nigeria.

Fasina Peace Oluwaseyi, University of Ibadan, Ibadan Nigeria. 


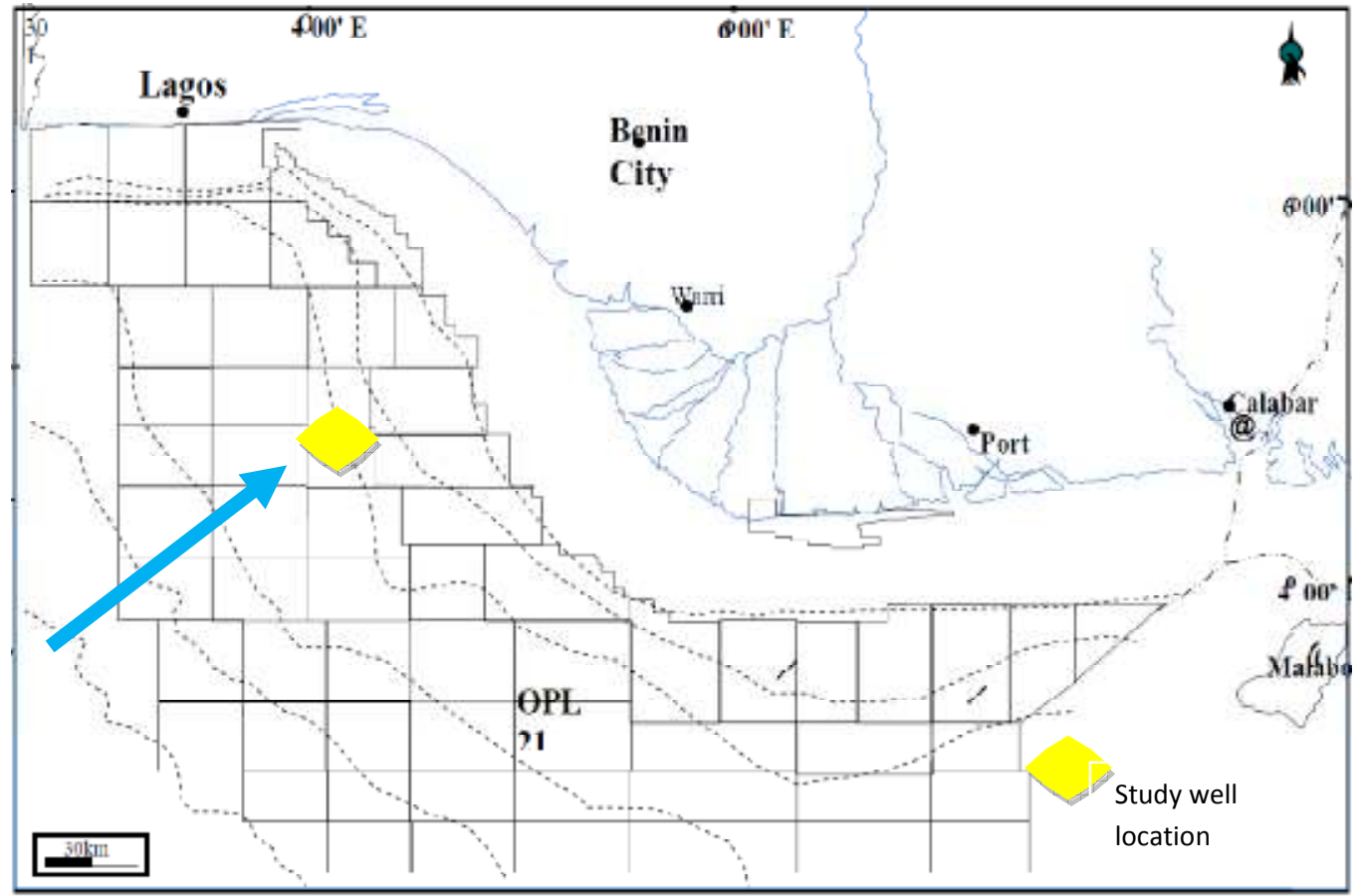

Figure 1: Map of Niger Delta Showing Study well location (Modified after Boboye et al, 2009).

\section{MATERIALS AND METHODS}

Twenty-five (25) ditch cutting samples from well AA, Offshore Niger Delta, at depth interval of $9000 \mathrm{ft}-11025 \mathrm{ft}$ and Gamma ray log data were provided by Shell Petroleum Company, Nigeria.

The ditch cutting samples were subjected to depth by depth analysis under a Stereo-binocular microscope to determine the lithologic, texture and fossil content following the procedures in by Swanson, (1981). Gamma ray log measures the differences in radioactivity between shales and sands, with a scale ranging from 0 150 API units. The higher and lower gamma ray readings were used to indicate the shale and sand units respectively. The lithology of the study interval was determine from both petrographic and gamma ray interpretations.

About $25 \mathrm{~g}$ of each ditch cutting samples was placed into aluminium sample preparation pan that were prelabelled. Each sample was soaked in Hydrogen peroxide overnight to disaggregate, and later decanted, topped with water and left overnight. Each samples was washed with distil water through the 63 micron sieve mesh and dried in an oven at temperature of $70^{\circ} \mathrm{C}$. The dried samples were later left to cool and subseqently put in labelled sachets bags for further examinations.

The packaged samples were taken under the microscope for identification of foraminifera species, with the guidiance of appropriate Foraminifera catalogues and literatures, including Loeblich and Tappan(1964, 1988); Cushman (1969). A check list was made of all foraminifera recovered and a distribution chart was produced. Photomonographs of some of the species recovered were taken (Figure 3 ).

\section{RESULTS AND DISCUSSIONS}

The lithologic units of well -AA, is dominated by greyish shale with streaks of fine - medium grained sands (Figure 2). The sand grain ranges from sub-angular to rounded and are poorly sorted to well sorted. Shale units had thicker intervals, from 9000ft - 9160ft, 9220ft $9310 \mathrm{ft}$, and $9370 \mathrm{ft}-11025 \mathrm{ft}$, with streaks of sand from $9170 \mathrm{ft}-9210 \mathrm{ft}$ and $9320 \mathrm{ft}-9360 \mathrm{ft}$. From gamma ray logs description and petrographic analysis, the sediments of well - AA were predominantly shale units (Fig. 2). 


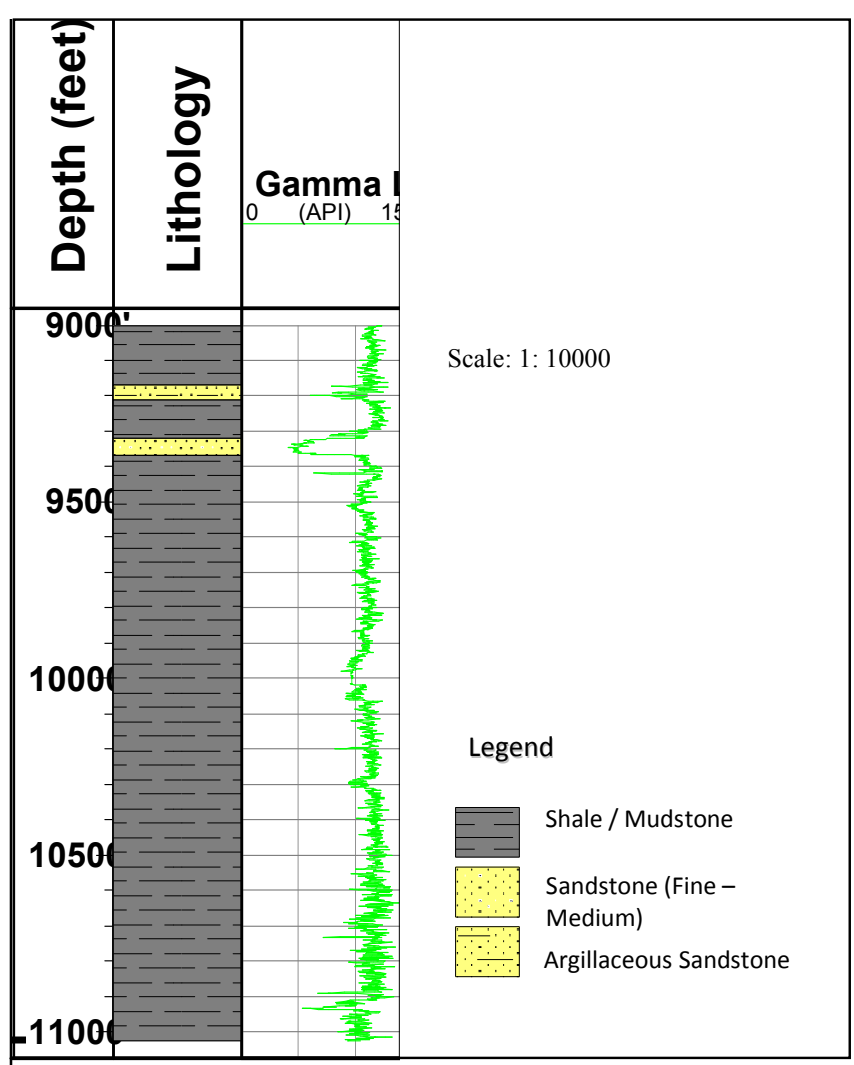

Figure 2: Lithologic description of well -AA.

\section{BIOSTRATIGRAPHY}

\section{Abundance and Diversity of Foraminifera}

Preservation of foraminifera assemblages in the ditch cutting samples of the study well was generally fair to poor. Foraminifera recorded included, calcareous benthic foraminifera - Lagena spp, agglutinated foraminifera - Haplophragmoides spp, Haplophragmoides narivaensis, arenaceous foraminifera - Cribrostomides spp, Bathysiphon spp and Trocahammina spp, Cyclammina spp and Valvulina spp, Cyclammina cancellata, Glomospira spp. (Fig. 4).

\section{BIOZONATION}

Planktic Foraminiferal Zonation

The absence of planktic foraminiferal in the well interval negates a definite planktic foraminiferal Zonation based on Blow $(1969,1979)$ zonation scheme.

Stratigraphic Interval $9000 \mathrm{ft}$ - 9360ft

Zone: Inderterminate

Age: indeterminate

Remarks

Interval barren of foraminifera (Figure 4).

Stratigraphic Interval 9360ft -11025ft:

Zone: N17 or older.

Age:? Middle-Late Miocene

\section{Remarks}

Interval characterized by absence of planktic and paucity of calcareous benthic foraminifera with a spot occurrence of Lagena spp at depth 9960ft. The top (FDO) of Haplophragmoides narivaensis which is commonly found within the N17 planktic zone has been used to delineate these interval.

\section{BENTHIC FORAMINIFERAL ZONATION.}

The well interval has been broadly zoned based on the observed agglutinated foraminiferal assemblage that dominated the well interval as follows:

Interval $9000 \mathrm{ft}$ - 11025ft;

Age:? Middle - Late Miocene

Zone: Haplophragmoides spp Zone

Remarks

Interval characterized by few to common occurrence of agglutinated foraminifera dominated by Haplophragmoides narivaensis and Haplophragmoides spp. Others include cribrostomides spp, Bathysiphon spp, Trochammina spp, Cyclammina spp, Cyclammina cancellata, Valvulina spp and Glomospira spp.

(Figure 4).

\section{PALAEOENVIRONMENT}

The analysed well interval has been tentatively assigned to the marine environment based on the distribution of deepwater arenaceous foraminifera species such as; Cribrostomides spp, Bathysiphon spp, Trocahammina spp, Cyclammina spp, Cyclammina cancellata, Valvulina spp and Glomospira spp. The predominance of the arenaceous forms over calcareous forms may also be interpreted as deposition in outer shelf dysoxic environment. 

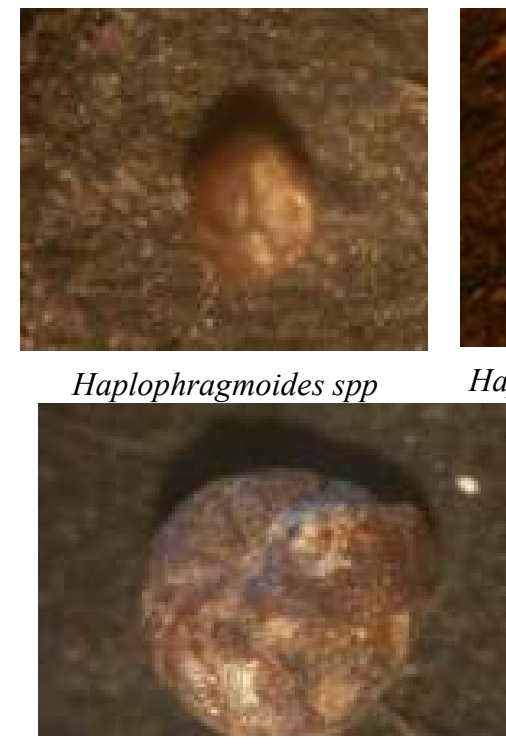

Trochammina spp

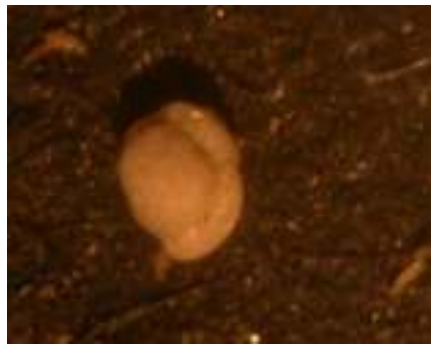

Haplophragmoides narivaensis

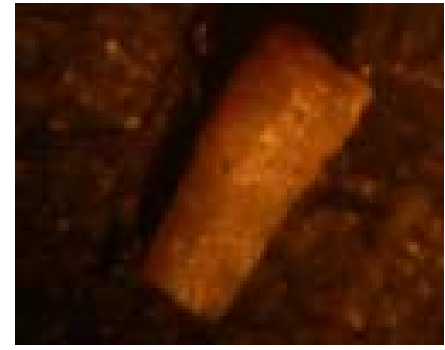

Bathysiphon spp

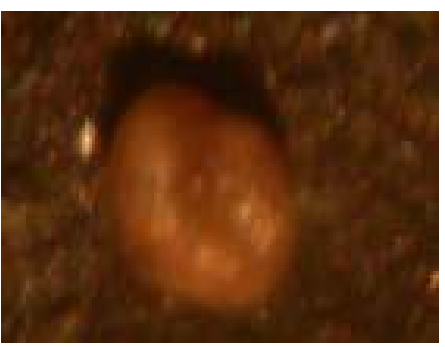

Valvulina spp

Figure 3. Photographs of some foraminifera recovered from the studied intervals

\section{CONCLUSION}

Foraminifera study has been carried out on Well-AA, offshore deepwater, Niger Delta within a depth interval of $9000 \mathrm{ft}-11025 \mathrm{ft}$. The lithology of the studied interval shows that the bulk lithofacies are grayish shales and fine - medium grain sandstones. The foraminifera assemblage in the study interval are poorly preserved and absent in planktic forms. The analysed section has tentatively been assigned to a Middle- Late Miocene (N17 and older), based on the First Downhole Occurrence (FDO) of Haplophragmoides narivaensis, an agglutinated foraminiferal species with FDO within the N17 Zone in the Niger Delta.

The section has been interpreted to be deposited in the marine environment based on the distribution of typical deep water arenaceous foraminiferal species. The predominance of the areneaceous forms over calcareous forms may also be interpreted as deposition in a outer shelf environment.

\section{REFERENCES}

Bassey, C. E., and Alalade, B., 2005. Late Miocene to Pleistocene Planktonic foraminiferal biostratigraphy and palaeoecology of North Apoi C Well, offshore western Niger Delta, Nigeria Journal of Mining and Geology, 41(1), 97-104.

Berggren, W. A., 1960. Rates of evolution of some Cenzoic Planktonic Foramiifera. Micropalaeontology,15(3),351-365.

Boboye O. A., and Adeleye, A. M., 2009: High Resolution Biostratigraphy of Early Pliocene Late Miocene Calcareous Nannoplankton and Foraminiferal, Deep Offshore, Niger Delta, Nigeria, European Journal of Scientific Research, 34(3), 308-325.
Boboye, O. A., Oladayo, A. S. and Okon, E. E., 2017. An Integrated Wireline-Log and Biostratigraphic Appraisal of Olure-1 and Abigboro-1 Wells, Onshore Niger Delta. Open Journal of Geology, 7, 1140-1159.

Blow, W. H., 1969. Late Middle Eocene to Recent Planktic Foraminiferal Biostratigraphy. Proceeding First International Conferences Planktonic Microfossils, Geneva, (1967), 199422.

Blow, W. H., 1979 The Cenozoic Globigerinida, E. J. Brill, Leiden, (3), 1413.

Cushman, J. A., 1969. Foraminifera: Their Classification and Economic Use. $4^{\text {th }}$ Edition. Harvard University Press, Massachusetts, 605.

Doust, H., and Omatsola, E., 1990. Niger Delta, in Edwards, J. D., and Santogrossi, P.A., (eds.), Divergent/passive margin basins, AAPG Memoir 48: Tulsa, American Association of Petroleum Geologists, 239-248.

Ekweozor, C. M., and Daukoru, E. M, 1994. Northern delta depobelt portion of the Akata-Agbada petroleum system, Niger Delta, Nigeria, in, Magoon, L. B., and Dow, W. G., eds., The Petroleum System--From Source to Trap, AAPG Memoir 60: Tulsa, American Association of Petroleum Geologists, 599-614.

Fadiya, S. L., 1999. Foraminifera and Calcareous Nannofossil biostratigraphy and well log sequence stratigraphic analysis of Opolo- 5 and Opolo-9 wells, Niger Delta. Unpub. M.Sc. Thesis, Department of Geology, Obafemi Awolowo University, Ile-Ife, Abstract Published- 
American Association of Petroleum Geologists Bulletin.1999;149:82(11),2162.

Fadiya , S. L., Jaiyeola-Ganiyu , F. A. and Fajemila , O. T., 2014. Foraminifera Biostratigraphy and Paleoenvironment of Sediments From Well AM 2, Niger Delta. Ife Journal of Science, 16(1), 61- 72.

Ifeoluwadun A. and Saka A. O., 2018. Foraminifera Biostratigraphy of Opolo -5 well Western Niger Deta, Nigeria Internal Journal of Advanced Scientific Research and Management, 3 (1) 39 48.

Klett, T. R., Ahlbrandt, T. S., Schmoker, J. W., and Dolton, J. L., 1997 Ranking of the world's oil and gas provinces by known petroleum volumes: U.S. Geological Survey.

Kulke, H., 1995. Nigeria, in, Kulke, H., (ed)., Regional Petroleum Geology of the World. Part II: Africa, America, Australia and Antarctica: Berlin, Gebrüder Borntraeger, 143-172.

Loeblich, A. R. Jr. and Tappan, H., 1964 Treatise on Invertebrate Paleontology, Part C, Protista. Vols. 1 and 2, Sacordina, chiefly Thecamoebians and Foraminiferida. Geological Society of America and University of Kansas Press, U.S.A

Loeblich, A. R. Jr. and Tappan, H. 1988. Foraminifera Genera and their classification. Van Nostrand Reinhold, New York, 1182.
Oloto I. N. and Promise, W., 2014. Biostratigraphic study and paleoenvironmental reconstruction of cores from offshore (South Western) Niger Delta, Nigeria. International Journal of Scientific \& Technology Research, 3, 279-286.

Omoboriowo, A. O., Edidem G. T., Awo Dogan O. L., Soronnadi-Ononiwu C. G., Oluwajana O. A., 2011. Foraminifera Biostratigraphy and Paleoenvironment of the ETOP well Deep Offshore, Niger Delta, Nigeria. International Journal of Science and Emerging Technologies. 2(3)87-94.

Ozumba, M. B., 1995. Late Miocene - Pliocene biostratigraphy offshore Niger Delta: Nigeria Association of Petroleum Bulletin, 10(01), 40 48.

Swanson, R. G., 1981 AAPG Sample Examination Manual, Shell Oil Company Exploration Training.

Umoh, E E, Ehinola O. A and Osterlof P. L., 2011 An assessment of abundance and distribution patterns of major Calcareous nannofossil as observed from Oligocene - Pliocene subsurface sediments of the Niger Delta, Nigerian Association of Petroleum Explorationists Bulletin, 23(2), 39-48.

Umoh, E. E., 2015. Assessment of spatial and temporal changes in Calcareous nannofossil productivity from Oligocene - Pliocene Strata, Niger Delta. Unpublished Ph.D. thesis 238p. University of Ibadan. 


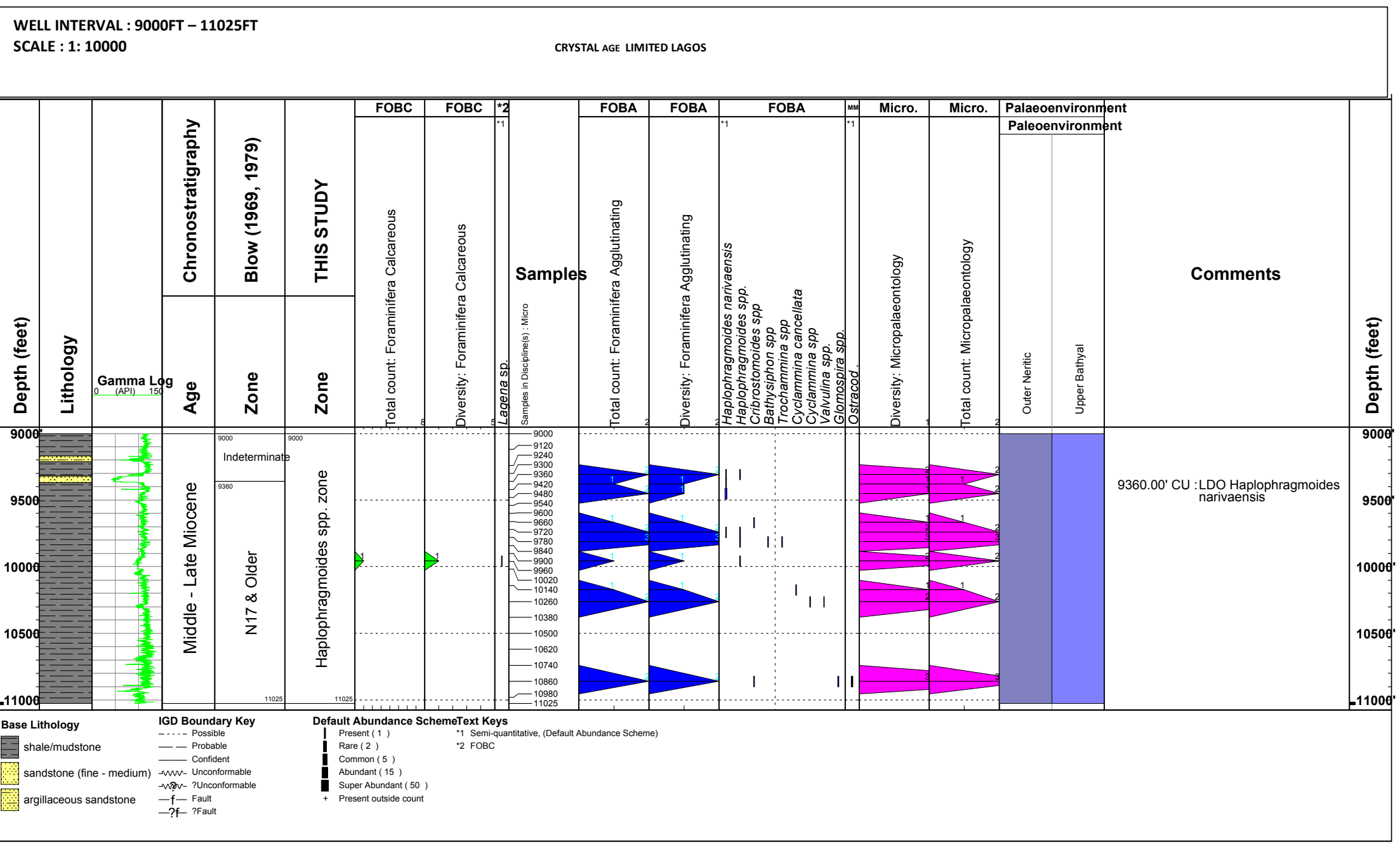

Figure 4: Foraminifera Distribution Chart for Well - AA. 